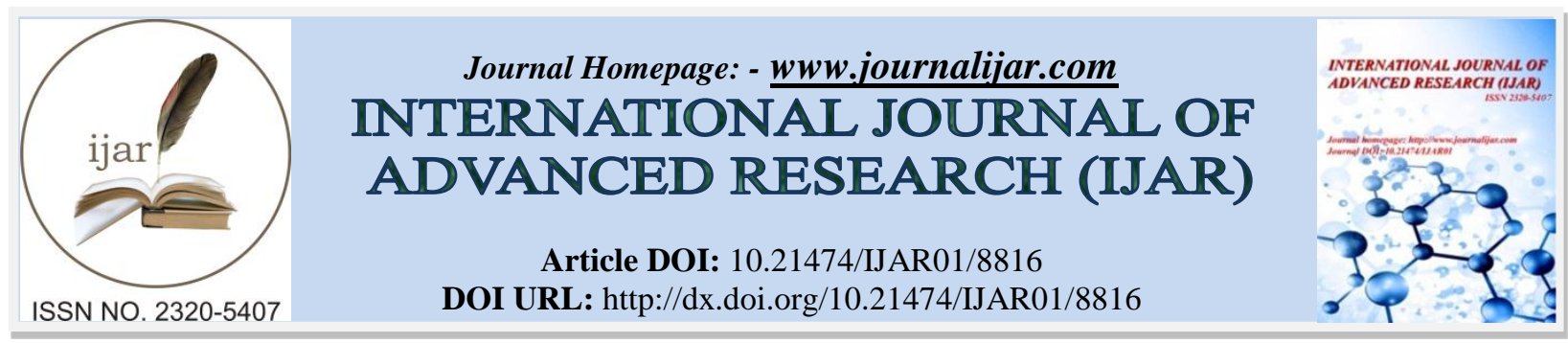

RESEARCH ARTICLE

\title{
RECONSTRUCTION OF LAW ENFORCEMENT IN THE CASE OF BANKRUPTCY BASED ON THE VALUE OF JUSTICE.
}

\author{
M. Rofian, Gunarto, Anis Mashdurohatun and Sri Endah Wahyuningsih. \\ Doctorate Student of Faculty of Law Unissula.
}

\section{Manuscript Info}

Manuscript History

Received: 05 February 2019

Final Accepted: 07 March 2019

Published: April 2019

Key words:-

Bankruptcy based on Justice Value.

\begin{abstract}
Bankruptcy are one of wrong solution for completing Debt disputes between debtors and creditor. Bankruptcy is a process in which debtor who has difficulties in finance to pay the debt stated a bankruptcy by commercial court because debtor cannot pay their debt. Rules that give away the law protection as per - manifestation of justice as stated in Law - No. 37 Year 2004 about Bankruptcy and Delay Obligations Payment Debt, Sheet of Country Republic Indonesia in 2004 Number 131, and Additional Sheet Country Number 4443 . The case of a debtor who does not voluntarily pay their debts, then creditors will file a lawsuit to the debtors to authorized civil court, and all property of the debtor will be a source of repayment of the debts to creditors. In case debtor have many creditors, and assets of the debtor are not sufficient to pay off all the creditors, the creditors will race in every way to get their money paid. Creditors who arrived later were no longer be able to get it because the debtor's assets had run out. The authors felt that this is very unfair and detrimental. Based on these reasons, a bankruptcy institution arose which regulated a fair procedures for paying creditors' bills. Provisions in Article 1 number 2 of Act Number 37 of 2004 specified that the creditor is a person who has accounts receivable because of an agreement or law that can be filed at court.
\end{abstract}

Copy Right, IJAR, 2019,. All rights reserved.

\section{Introduction:- \\ PRELIMINARY}

A. Background

The credit sector is one of the means of a developing capital for the business community[1] . For entrepreneurs, taking credit is a factor that cannot be separated from business life [2].

When the process of applying for a loan, the debtor must have good faith and must be able to convince the creditor that the debtor will be able to return the loan. Without trust ( trust ) from creditors to the debtor, the creditor will not give credit or loan.[3]

Legal relations between creditors and debtors occur when both parties sign a debt agreement. With the signing of the debt agreement, the two parties have agreed to the contents and intent of the agreement, and thus apply the principle of binding power, namely the binding of the parties to the agreement not only limited to what was agreed upon, but also against other elements as long as desired by habits and propriety and morals, so that the moral principles, 
propriety, and habits of binding the parties. In a consensual agreement, the Civil Code (KUHPerdata) determines that immediately after an agreement is made, an agreement is born, which at the same time also issues an agreement between the parties that have agreed and promised [4].

Based on Article 32 of Law Number 40 of 2007 concerning Limited Liability Companies, if it runs and develops its business, it has debts from two or more creditors and if it is no longer able to pay its debt to creditors it can be declared bankrupt. The choice for the bankruptcy of a company becomes an alternative to settling debts through the institution of bankruptcy law in the judiciary quickly, fairly, openly and effectively. Considering that the settlement of debts through civil court requires a long time, the government issues Government Regulation in Lieu of Law Number 1 of 1998 concerning Amendment to the Bankruptcy Act of 1905. This regulation is then passed into a Number Law. 4 of 1998 and then changed to Law Number 37 of 2004. The objectives of bankruptcy law are as follows: [5]

1. To guarantee the equal distribution of the debtor's assets among creditors;

2. Preventing the debtor from committing actions that can harm the interests of creditors;

Provide protection to debtors with good intentions from their creditors by obtaining exemption.

\section{B. Formulation of the problem.}

Based on the description in the background of the problems mentioned above, the problems in this study can be formulated as follows:

1. Why is the regulation of law enforcement in bankruptcy cases in the judicial process not yet fair?

2. What are the weaknesses of law enforcement in the case of bankruptcy in the current judicial process?

\section{Purpose and Use of Writing .}

From the description of the background and subject matter above, the purpose of this study is to analyze the implementation of bankruptcy law enforcement in a justice process that is not yet fair. In addition, it also analyzes the weaknesses of the bankruptcy law enforcement process in the current judicial process. Then the reconstruction of law enforcement must be carried out in a bankruptcy case based on justice value.

\section{Literature Study}

a. Justice Theory in Philosophy of Islamic Law

The problem of justice according to Islamic law, is inseparable from the philosophy of Islamic law and the theory of the purpose of Islamic law, which in principle is how to realize the "usefulness" of all humanity, which includes "usefulness" in life in the world and in the hereafter.

b. Theory of Pancasila Justice

The Pancasila State is a nation of social justice, which means that the state as the incarnation of God as the Supreme Being, the nature of individuals and social beings aims to bring about justice in life together (social justice). Social justice is based and inspired by the essence of human justice as civilized beings (Second Precept). Humans are essentially just and civilized, which means that they must be fair to themselves, fair to God, fair to others and society and fair to their natural environment.[6]

\section{E. Method Of Research}

In this study using the construct-tivism paradigm, a paradigm that considers that legal science only deals with mere legislation. Law is something that must be applied, and is more likely not to question the value of justice and its use for the community. Legal studies and enforcement only revolve around what is right and what is not true, what is wrong and what is not wrong and other forms that are more prescriptive. The ultimate goal is to get a consensus construction that is more mature and sophisticated than all previous constructions (including, of course, the construction of researcher ethics). [7]This research approach is sociological juridical, meaning that the results of this study try to provide a comprehensive picture, deep and real research conducted on the real situation of the community or community environment with the intent and purpose of finding facts ( fact-finding), which then towards problem identification and ultimately lead to problem solving [8].

\section{RESULTS AND DISCUSSION:-}

\section{A. the regulation of law enforcement in bankruptcy cases in the judicial process}

To overcome this condition, the right step to resolve it, both for the benefit of creditors and debtors is to provide benefits for both parties. Many steps can be taken to overcome these problems, one of which is to file a bankruptcy application. 
Bankruptcy is one way out to resolve debt-debt disputes between debtors and creditors. Bankruptcy is a process in which a debtor who has financial difficulties to pay his debt is declared bankrupt by the court in this case in the Commercial Court because the debtor can no longer pay his debts[9]

Rules that give away protection law as form per - manifestation of justice stated on Law - No. 37 Year 2004 about Bankruptcy and Delay Obligations Payment Debt, Sheet Country Republic Indonesia in 2004 Number 131, Additional Sheet Country Number 4443 .

Rules that provide legal protection as a form of justice are stated in Law Number 37 of 2004 concerning Bankruptcy and Delay of Obligation to Pay Debt, State Gazette of the Republic of Indonesia of 2004 Number 131, Supplement to State Gazette Number 4443.In the event that a debtor does not pay his debt voluntarily, then the creditor will sue the debtor in a civil manner to the competent District Court, and all the debtor's assets become the source of his debt repayment to the creditor. In the event that the debtor has many creditors, and the debtor's assets are not enough to pay off all creditors, then the creditors will compete in every way to get the bill paid in full. Creditors who arrived later were no longer able to pay because the debtor's assets had run out. This is very unfair and detrimental. Based on these reasons, a bankruptcy institution arises that regulates fair procedures regarding the payment of creditors' bills.[10]

The provisions of Article 1 number 2 of Act Number 37 of 2004 apply specify that the creditor is a person who has accounts receivable because of an agreement or law that can be billed at court. The principle - it is The creditor can be an individual or legal entity. Then, in the light of Article 2 (1) of Law Number 37 Year 2004 which meant that the concurrent creditor, separatist creditors and preferred creditors. Especially with regard to the separatist creditor and preferred creditor, they can either submit repayment of payment of receivables without losing the collateral rights to the property held against the debtor property and its right to take precedence.

Separatist creditors are holders of material security rights that authorize the creditor to sell the material auction guaranteed to him for repayment compared to other creditors . In principle, the separatist creditor consists of : [11]

1. Pawn holder as stipulated in the provisions of Article 1150 - Article 1160 Book III of Chapter XX of the Criminal Code which applies to movable objects. Basically, normatively against mortgage, mortgage provider (debtor) must release their control of an object (Pawned) to the recipient pawn (creditors);

2. Holders of Mortgages on vessels registered with the gross tonnage is 20 (twenty) square metre. This aspect is listed in the Syahbandar, with the registration of ships are Indonesian ships (Article 314 KUHD) and practice aircraft is also listed as the provisions of the Geneva Convention 1948 on the Convention on the International recognition og Rights in Aircrafts. Mortgages are regulated in the provisions of Article 1162 - Article 1232 of the Civil Code. Basically, according to the provisions of Article 314 KUH D, ships are treated as immovable material so that guarantees can be placed on it is also only in the form of mortgages. As for unregistered vessels, it is considered as a movable material for which the provisions of Article 1977 of the Civil Code apply to movable objects which are not in the form of interest and receivables that do not have to be paid to the carrier. The logical consequence means a ship with a size of less than 20 (twenty) square metre of dirty contents, which is not registered can be pawned;

3. Encumbrance, as stipulated in Law No. 4 of 1996 concerning the guarantee of the rights of certain lands following material which is inherent and used jointly in the concerned plot;

4. Fiduciary, it as provided in Article 3 of Law No. 42 of 1999 on Guarantee of fiduciary where it does not apply to security rights relating to land and buildings, buildings on land owned by another person who can not encumbered encumbrance, can be an object of fiduciary guarantee, then mortgages on ships registered with dirty contents measuring 20 (twenty) square metre or more, mortgages on airplanes and pawns.

Preferred creditors have special or privileged debts as stipulated in Article 1139 and Article 1149 of the Civil Code. The provisions of Article 1131 of the Civil Code determine that all objects of a person are borne by all of their debts. The sale of these items must be divided between the debts according to the balance of the amount of the receivables, except if there are temporary persons who by law are given the right to take repayments in advance from other collectors (Article 1132 of the Civil Code). The provisions of Article 1133 of the Civil Code state that they are collectors who have rights arising from privileges, pawns and mortgages, then the provisions of Article 1134 of the Civil Code determine privilege is a special position from a collector who is given a law based on the nature of accounts receivable. [12] 
The principle, states that new privileges arises when the confiscated wealth is not enough to pay off all debts. Therefore, this privilege position is lower than mortgage, encumbrance, fiduciary guarantees, unless the law determines otherwise, then the concurrent creditor has ordinary accounts (bevoorrechte schulden) that are not guaranteed by pawning, fiduciary guarantees, mortgages or mortgages and the payment is made in a balanced manner. Basically, concurrent creditors are creditors who have the rights to pari passu prorata parte, creditors get repayments together without prior rights, calculated the amount of each receivable to the receivables as a whole from all debtor assets. [13]

Supreme Court of republic of Indonesia outlined that applicants meet the requirements to apply for a bankruptcy case in the Commercial Court, as follows :

1. Letter of application for stamp duty addressed to all Commercial Courts;

2. Advocate Card;

3. Evidence that shows the existence of an agreement (sale and purchase agreement, debt - receivables, court decision, commercial paper, invoice, receipt, etc.);

4. Procuration;

5. Company Registration Certificate (TDP) / Associated / Founded Foundation legalized (stamped) by the Trade Office no later than 1 (one) week prior to entry will - late registration;

6. Details of unpaid debt;

7. Indonesian translation by an official translator (sworn), when it comes to foreign languages;

8. The name and address of each of the creditors / debtor.

Bankruptcy institution which is a further arrangement of what is stipulated in Article 1131 jo. Article 1132 of the Civil Code (B W ) concerning the principle of "creditorium parity" and the principle of "pari passu prorata parte" which is the main principle of debt settlement from debtors to their creditors. BW Article 1131 states that: "All the material Air - debt, whether moving or not moving, both existing and new will exist in the future, be dependent on any contract".

\section{B. Reconstruction Of Law Enforcement In Bankruptcy Cases Based On Fair Value .}

Law enforcement is a duty. Tasks imposed by law enforcement officials, and because of the assignment, then as Kant said, it was a "categorical obligation", " absolute obligation ". Here do not know the term, " with conditions". Law enforcement must pay attention to ethics. There are also places of ethics in law enforcement, namely:

1. Tasks are tasks, must be carried out. This is the first place of ethics in law enforcement, namely (ethical) awareness about the obligation to carry out obligations;

2. The second place of ethics is to obey principles. Law enforcement must be based on law. Law enforcement must not occur by breaking the law. If this is the case, in ethics, it's called "the way to achieve the goal" (the end justifies the means), and this is ethically disgraceful;

3. The third place of ethics is the value of the task of law enforcement itself. The task of law enforcement is a noble, noble, and full of duty. The task of civilization is to maintain a human community that is humane through the management of law and justice. There can be no human life together without law and justice. Human communicacies will soon turn out to be animal communities if law and justice are no longer a binder of the joints of life, and law enforcement officials are assigned to maintain it. Their job is not an ordinary task. Their duty is the task of civilization. Presenting humane human communities. The nobleness of their assignment lies there, and there is also the honor of their raison d'etre. Ethical issues here are the ethical implications of the honor of the law enforcement duties;

4. The fourth place of ethics is to appreciate the identity of the apparatus as a law enforcer. The task of enforcing the law is a task that requires seriousness and determination. The whole process of law enforcement, in addition to asking for accuracy, is also very laden with temptation. Therefore, the ethical issue here is how the seriousness and determination of the apparatus / institution faces all these temptations;

5. The fifth place of ethics is to carry out the task of distributing justice. The task of law enforcement is actually the task of distributing justice. The ethical issue here is how the law apparatus, through handling a case, distributes justice for the state / community, victims, and also the perpetrators;

6. The sixth place of ethics is in the service of law enforcement officers. The ethical issue here is whether the concrete manifestation of law enforcement is indeed valuable and beneficial to the community and justice seekers;

7. The seventh place of ethics is in the behavior of legal officers in the organizational context and institutional management. The ethical issue here is how it should act when facing a dilemma between the demands of the task and the policy of the organization / leadership.The process of law enforcement is a process that is loaded with 
ethical questions. The apparatus that runs the process is not only facing the techniques of implementing the law. In the judicial process, where there is interaction between laws and regulations, administrative practices, institutional policies, the individuality of the apparatus, and the struggle of the suspect, the law enforcement process, inevitably, will intersect with ethical issues.

The law enforcement process is a process that is full of per ethical questions. Officials who run the process, not only the air - before the techniques of application of the law. In the judicial process, where there is interaction between laws and regulations, administrative practices, institutional policies, the individuality of the apparatus, and the struggle of suspects, the law enforcement process, inevitably, will intersect with ethical issues.

Ethics has to do with something that humans should do as humans. Certain predicates socially, politically, and economically that a person has does not reduce his obligation to act "what should be" as a human being. The reality of a person who has a position or does not have a position, only as a variable that also determines the quality of his ethical actions, but does not at all reduce the obligation to do as much as possible the "right", "good", and "right", or vice versa, do not do "wrong", "bad", and "inappropriate"

Basically in Law Number 37 of 2004 provided the legal potential protective on concurrent creditor against the debtor bankrupt, creditors separatist, curator and supervisory judge, namely:

1. Potential protective law to concurrent creditors against the debtor bankrupt;

a. $\quad$ Confiscation guarantee (Article 10);

b. $\quad$ Decision and merit [ Article 8 paragraph (7) and Article 16) ];

c. $\quad$ Silence [ Article 24, Article 25, Article 27, Article 34, Article 40 paragraph (1), and Article 97);

d. $\quad$ Actio pauliana (Article 30 and Article 41 - Article 47);

e. $\quad$ Enforcement Bodies (Article 93 - Article 96);

f. To secure bankruptcy assets (Article 99),

g. $\quad$ requests for rehabilitation appeal (Article 218 and Article 220);

h. $\quad$ supervision on communications debtors (Article 105).

2. Legal protection of creditors concurrent with separatist creditors ;

a. $\quad$ enforceability (Article 56);

b. Limit the period of execution and purchase of collateral items (Article 59), and

c. Liability of the sale of collateral objects [Article 60 paragraph (1) and (2)].

3. Creative legal protection is concurrent with the curator.

a. Responsible curator [ Article 72, Article 74 paragraph (1) and paragraph (2), Article 78 paragraph (2), Article 143 paragraph (1), and Article 202 paragraph (3)];

b. $\quad$ Replacement of curators (Article 71);

c. $\quad$ appeal to the curator acts (Article 77 and Article 193); and

d. $\quad$ supervision to an inventory conducted curator (Article 100).

4. Legal protection for creditors concurrent with the supervisory judge.

There are provisions regarding appeals for the establishment of supervising judges through the Commercial Court (Article 68).Based on these articles, Law No. 37 of 2004 has provided legal protection for concurrent creditors to obtain their rights to debtor assets that have been declared bankrupt, there are only a few articles that contain weaknesses so they must be deleted, replaced or revised.

It is also necessary in this regard to know bankruptcy law from other countries to settle bankruptcy cases as a comparative law that Indonesia can emulate to renew its bankruptcy law. The following can be described in the United States bankruptcy law:

Reconstruction of Law Enforcement in the Case of Bankruptcy Based Values

\begin{tabular}{|l|l|l|l|}
\hline No. & Before Reconstruction & Weakness & The construction \\
\hline 1. & Article 2 paragraph (1) Law & The minimum requirement of two & The debtor is able to pay the \\
& 37/2004 reads: "A debtor who has & creditors can file for bankruptcy & bills amounting to at least \\
& two or more creditors and does & debtors lose money right, because & $75 \%$ of the value of credit \\
not pay in full at least one debt & it will easily be bankrupted by & and do not pay in full of the \\
that has matured and can be & creditors. Because there could be & debt that has been past the \\
billed, is declared bankrupt with a & creditors whose receivables are due and could be charged \\
\hline
\end{tabular}




\begin{tabular}{|c|c|c|c|}
\hline & $\begin{array}{l}\text { court decision, either on his own } \\
\text { request or on the request of one or } \\
\text { more his creditors ". }\end{array}$ & $\begin{array}{l}\text { not due due to being forced to } \\
\text { participate in filing for bankruptcy } \\
\text { applications. }\end{array}$ & $\begin{array}{l}\text { with considering the health } \\
\text { end of the debtor financial, } \\
\text { and hindered in declaring } \\
\text { bankruptcy with supervision } \\
\text { to avoid unfair verdict - an, } \\
\text { well above appeal on } \\
\text { themselves want even at the } \\
\text { request of } 75 \% \text { of creditors. }\end{array}$ \\
\hline 2. & $\begin{array}{l}\text { Article } 10 \text { paragraph (1) letter a } \\
\text { of Law } 37 / 2004 \text {, reads: " Placing } \\
\text { seizure guarantees for part or all } \\
\text { of debi - tor wealth". }\end{array}$ & $\begin{array}{l}\text { It takes time to file a confiscation } \\
\text { to the Federal Court. }\end{array}$ & $\begin{array}{l}\text { With the per - plea for } \\
\text { bankruptcy by the debtor and } \\
75 \% \text { of concurrent creditor's, } \\
\text { then some or all of the } \\
\text { wealth of the bankruptcy } \\
\text { debtor becomes collateral } \\
\text { debtors. }\end{array}$ \\
\hline 3. & 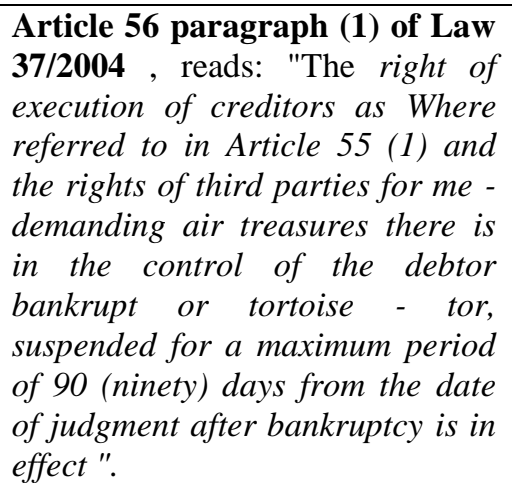 & $\begin{array}{l}\text { Contrary to Article } 55 \text { paragraph } \\
\text { (1) of Law } 37 / 2004 \text {, which reads: } \\
\text { "With due regard to the provisions } \\
\text { referred to in Article 56, Article } \\
57 \text {, and Article 58, each creditor } \\
\text { is a pawn holder, fiduciary } \\
\text { guarantee, } \\
\text { encumbrance or collateral right } \\
\text { for other materials, it can execute } \\
\text { its rights as if there was no } \\
\text { bankruptcy". }\end{array}$ & $\begin{array}{l}\text { Article } 56 \text { of Law } 37 / 2004 \text { is } \\
\text { deleted. }\end{array}$ \\
\hline 4. & $\begin{array}{l}\text { Article } 281 \text { paragraph (1) letter } \\
\text { b of Law } \mathbf{3 7 / 2 0 0 4 , ~ r e a d s : ~} \\
\text { "Approval of more than 1/2 (one } \\
\text { half) the amount of the creditor's } \\
\text { receivable is secured by a pledge, } \\
\text { ja-min late fiduciary, the right of } \\
\text { encumbrance, mortgages, or the } \\
\text { right collateral for other } \\
\text { materialistic present and } \\
\text { representing at least } 2 / 3 \text { (two third) } \\
\text { part of all bills from that creditor } \\
\text { or I- usually those present at the } \\
\text { meeting". }\end{array}$ & $\begin{array}{l}\text { Inhibiting the submission of peace } \\
\text { because of the high number of } \\
\text { voting requirements, and the } \\
\text { credible creditors have been } \\
\text { guaranteed, so there is no need to } \\
\text { participate in voting. }\end{array}$ & $\begin{array}{l}\text { Article } 281 \text { paragraph (1) } \\
\text { letter b of Law } 37 / 2004 \text { is } \\
\text { abolished. }\end{array}$ \\
\hline 5. & $\begin{array}{l}\text { Article } 222 \text { paragraph (1) of } \\
\text { Law } 37 / 2004 \text {, reads: "the delay of } \\
\text { Liabilities fullfilment - Debt } \\
\text { payments filed by debtors that } \\
\text { possess more than } 1 \text { (one) the } \\
\text { creditor or creditors". }\end{array}$ & $\begin{array}{l}\text { Debtors are more aware of } \\
\text { financial health conditions the }\end{array}$ & $\begin{array}{l}\text { Obligatory Delay Debt } \\
\text { Payments late filed by } \\
\text { debtors who have more than } \\
1 \text { (one) creditor" }\end{array}$ \\
\hline
\end{tabular}

Reconstruction of the value of law enforcement in bankruptcy cases based on justice is to realize:

1. The distribution of bankrupt debtor property fairly and proportionally based on the pari passu prorata parte principle ;

2. Seeking peace in the payment of creditors' debts, both separatist creditors and concurrent creditors without destroying the debtor's business. The postponement of debt repayment obligations is given in a broad period of time in order to improve the financial health of the debtor company optimally. The debtor is still given full authority to continue to take care of the company as long as the postponement of debt repayment obligations takes place , of course with supervision. It is also necessary to sample the Debtor in Possession in Chapter 11 Bankruptcy Code in the United States ; 
Law enforcement in bankruptcy cases by seeking a win-win solution. Therefore, it is necessary to revise Law Number 37 of 2004, more explicitly regulating: (a) the order of creditors 'receivables, (b) the period of restructuring of bankrupt debtor companies, and (c) automatic stay for bankrupt debtors' assets; Need to establish a special institution that regulates bankruptcy cases; Need to implement bankruptcy law from the United States of America, especially regarding automatic stay and debtor in possession.

\section{Conclusions And Suggestions:-}

1. The enforcement of bankruptcy law in the judicial process as regulated in Law Number 37 of 2004 concerning Bankruptcy and Postponement of Payment Obligations, which starts from filing bankruptcy applications to the head of court, registering applications, court hearings, decisions on bankruptcy applications, against the decision to file a bankruptcy application can be filed a cassation to the Supreme Court, in a bankruptcy decision appointed a curator and supervisory judge, the debtor has the right to offer peace to the creditors, if the peace is refused, the curator can take action in the interests of the bankrupt debtor's assets. bankruptcy with the approval of the supervisory judge, after the bankruptcy of the debtor's assets is distributed, the curator makes an announcement in the newspaper, and after the bankruptcy ends, the debtor has the right to apply for rehabilitation. In addition, the debtor and creditor can submit a delay in the debt repayment obligation, but the decision on the postponement of the debt repayment obligation cannot be submitted by any legal remedy. However, in the implementation of bankruptcy law in the Commercial Court has not been able to provide justice, especially for concurrent creditors, has not been able to provide justice because of the weaknesses both in the substance of Law Number 37 of 2004, in the structure of law enforcement, namely curators and judges trade, and in its legal culture, namely the goodwill of the parties;

2. Weaknesses in the bankruptcy law enforcement process in the judicial process consist of (a) weaknesses in the field of legal substance, namely weaknesses in articles in Law Number 37 Year 2004, including: Article 2 paragraph (1), Article 10, Article 56, Article 225 paragraph (4), Article 281, Article 76, and Article 222 paragraph (1); (b) weaknesses in the legal structure, namely the authority of a large curator so that it must be limited, as well as commercial judges who are passive and do not understand the ins and outs of bankruptcy; and (c) weaknesses in legal culture, namely the presence of bad faith from parties and parties involved in bankruptcy cases, including the attitude of non-cooperative debtors, creditors who do not care about other creditors, and individuals who seek profits in in the bankruptcy process, so that the settlement of bankruptcy cases becomes hampered and hampered because Basically in Law No. 37 of 2004 it has provided legal protection to creditors concurrently to the actions of bankrupt debtors, separatist creditors, curators and supervisory judges, namely: (a ) legal protection for concurrent creditors against bankrupt debtors: collateral seizure (Article 10), immediate decision [Article 8 paragraph (7) and Article 16)], silence [Article 24, Article 25, Article 27, Article 34, Article 40 paragraph (1), and Article 97), Actio pauliana (Article 30 and Article 41 - Article 47), forced bodies (Article 93 - Article 96), bankrupt assets sealing (Article 99), objections to and request for rehabilitation (Article 218 and Article 220), and supervision of debtor communication (Article 105); concurrent creditor legal protection of separatist creditors, namely: suspension of execution (Article 56), limitation of the period of execution and purchase of collateral objects (Article 59), and accountability for the sale of collateral [Article 60 paragraph (1) and paragraph (2)]; (c) the legal protection of concurrent creditors to the curator, namely: the responsibility of the curator [Article 72, Article 74 paragraph (1) and paragraph (2), Article 78 paragraph (2), Article 143 paragraph (1), and Article 202 paragraph (3)], replacement of the curator (Article 71), objection to the curator's actions (Article 77 and Article 193), and supervision of the inventory carried out by the curator (Article 100); and (d) legal protection for concurrent creditors to supervisory judges, namely: the existence of provisions regarding appeals on the determination of supervisory judges through the Commercial Court (Article 68). However, the existence of several juridical weaknesses in the article of the Act must be removed, replaced or revised. Related to the legal protection of concurrent creditors in the context of the bankruptcy case law enforcement process based on Law Number 37 of 2004, it can be done by attempting to bring peace and delay the obligation to pay debt. 


\section{Bibliography:-}

1. B. L. Tanya, Law Enforcement in the Light of Ethics. Yogyakarta: Genta Publishing, 2011.

2. "Judge of the Commercial Court in the Semarang District Court,Interview." .

3. I. Ikhwansyah, S. D. Judiasih, and R. S. Pustikasari, Bankruptcy Law, Legal Analysis of Disputes \& Family Law and Marriage Assets. Bandung: Keni Media, 2012.

4. K. Muljadi and G. Widjaja, Mortgage Rights, Wealth Law Series. Jakarta: Kencana Prenada Media Group, 2008.

5. L. Mulyadi, "Bankruptcy Case and Postponement of Debt Payment Obligations (PKPU) Theory and Practice," Complete with Decisions of Commercial Courts, Bandung, 2010.

6. M. H. Shubhan, Bankruptcy Law: Principles, Norms, and Practices in the Judiciary. Jakarta: Kencana Prenada Media Group, 2008.

7. N. K. Denzin and Y. S. Lincoln, Handbook of Qualitative Research, translated by Dariyatno, Badrus Samsul Fata, Abi, John Rinaldi, Student Library. Yogyakarta, 2009.

8. S. R. Sjahdeini, G. Rights, and Bankruptcy, Comparative Papers in the Seminar on Dissemination of Law Number 42 of 1999 concerning Fiduciary Guarantees. Jakarta, 2000.

9. S. R. Sjahdeini, Bankruptcy Law Understanding Law Number 37 Year 2004 concerning Bankruptcy, no. 3. Jakarta, 2009.

10. S. R. Sjahdeini, "Bankruptcy Law , Understanding Law No. 37 of 2004 concerning Bankruptcy," Graffiti M., Jakarta: concerning Bankruptcy, 2008, p. 37.

11. S. Soekanto, Introduction to Legal Research. Jakarta: UI Press, 1982.

12. I. Danisworo, "Analysis of Comparison of Indonesian Bankruptcy Law with Bankruptcy Law in the United States," http://lib.ui.ac.id/naskahringkas/2015-09/S44865-Ibnu\%20Danisworo. .

13. "http : // kartikarahmah 2406. wordpress . com / 2012/12/02 / theory - justice - social , downloaded on March 15, 2017, at: 19:00 WIB." 